\title{
Molekularne mechanizmy działania czynnika transkrypcyjnego FOXN1 w skórze
}

Barbara Gawrońska-Kozak*, Anna Kur-Piotrowska, Joanna Wiśniewska, Marta Kopcewicz

Instytut Rozrodu Zwierząt i Badań Żywności, Polska Akademia Nauk w Olsztynie

Abstrakt

Artykuł jest przeglądem wyników badań dotyczących funkcji i mechanizmu działania czynnika transkrypcyjnego FOXN1. Lokalizacja FOXN1 u przedstawicieli wszystkich ssaków ogranicza się do nabłonka tylko dwóch organów: skóry i grasicy. W skórze FOXN1 stymuluje różnicowanie się keratynocytów, reguluje proces pigmentacji i bierze udział w rozwoju włosów. W skórze objętej urazem FOXN1 jest zaangażowany w bliznowy proces gojenia poprzez udział w reepitelializacji oraz w procesie przejścia epitelialno-mezenchymalnego (epithelial-mesenchymal transition; EMT). Pozbawione aktywnego czynnika transkrypcyjnego FOXN1 dorosłe myszy (Foxn1-/-) goją urazy skórne w unikalnym, charakterystycznym jedynie dla płodów ssaków, procesie bezbliznowej (scar-free) regeneracji. Analiza porównawcza transkryptomów skóry: dorosłych myszy Foxn1-/- oraz skóry płodów myszy (14. dzień rozwoju płodowego) wykazała istotne podobieństwa w ekspresji genów związanych przede wszystkim z przebudową tkanek, budową cytoszkieletu, gojeniem urazów, odpowiedzią immunologiczną oraz różnicowaniem. Wyniki te wskazują, iż FOXN1 może być głównym elementem szlaku sygnałowego na drodze tzw. punktu tranzycyjnego czyli przejścia z etapu gojenia bezbliznowego (płodowego) do bliznowego (dorosłego) w trakcie rozwoju płodowego.

Słowa

kluczowe

czynnik transkrypcyjny • FOXN1 • skóra • regeneracja • blizna

Otrzymano: 01.10.2020, Zaakceptowano: 17.06.2021

Abstract

The review focuses on the research related to the function and the molecular mechanisms of transcription factor FOXN1 action. In mammals, FOXN1 is localized in the epithelium of the skin and thymus. In the skin, FOXN1 stimulates keratinocytes differentiation, regulates pigmentation process and participates in hair development and cycling. In skin wound healing processes, FOXN1 contributes to scar formation due to its involvement in reepithelialization and epithelialmesenchymal transition (EMT). Foxn1\% mice displayed regenerative (scar-free) skin wound healing resolution, which is unique for adult mammals but characteristic for mammalian fetuses. A detailed comparative analysis of transcriptomes from the skin of adult Foxn1\% mice and the skin of mouse fetuses (14 ${ }^{\text {th }}$ day of embryonic development) revealed substantial similarities in the gene expression related to tissue remodelling, cytoskeletal rearrangements, wound healing, the immune response and differentiation. The results suggest that FOXN1 is a key factor regulating the transition from scar-free (regenerative) to scar-forming (reparative) skin wound healing process during fetal development

Keywords

Transcription factor • FOXN1・skin • regeneration • scar

Received: 01.10.2020, Accepted: 17.06.2021

*Corresponding author e-mail: b.kozak@pan.olsztyn.pl

() Br-Nc-ND $\odot$ 2021Barbara Gawrońska-Kozak et al. This work is licensed under the Creative Commons Attribution-NonCommercial-NoDerivs 4.0 License. 


\section{Budowa i funkcje skóry}

Skóra jest największym, wysoce zorganizowanym organem ciała; pełni funkcje ochronne, sensoryczne i immunologiczne oraz uczestniczy w komunikacji endokrynnej i neuronalnej [1, 2]. Jest zbudowana z naskórka, tworzącego bezpośrednią barierę oddzielającą organizm od środowiska leżącej poniżej skóry właściwej. Obie warstwy: naskórek i skóra właściwa są oddzielone od siebie błoną podstawną (ryc. 1).

Naskórek charakteryzuje się budową wielowarstwową; warstwa przylegająca do błony podstawnej to warstwa podstawna (bazalna), po niej następują warstwy: kolczysta, ziarnista i najbardziej zewnętrzna warstwa rogowa. Obecne w warstwie podstawnej (rozrodczej) komórki macierzyste i progenitorowe zapewniają nieustanną zdolność naskórka do odnowy, a nowo powstające keratynocyty opuszczają warstwę podstawną i rozpoczynają migrację w kierunku zewnętrznej powierzchni skóry, ulegając licznym przemianom biochemicznym i morfologicznym. W czasie migracji keratynocyty, regulowane aktywnością czynników transkrypcyjnych, tracą zdolność do proliferacji i przechodzą następujące po sobie stadia różnicowania, tworząc kolejne warstwy naskórka (ryc. 1). Komórki każdej z warstw charakteryzują się ekspresją swoistych markerów, np. keratyny $14 \mathrm{w}$ warstwie podstawnej, keratyny $10 \mathrm{i}$ inwolukryny w warstwie kolczystej (ryc. 1) [3]. Oprócz keratynocytów, głównego budulca naskórka, obecne są w nim również: melanocyty i komórki Langerhansa [4].

W skórze właściwej wyróżnia się zasadniczo trzy warstwy: przyległą do naskórka warstwę brodawkowatą (papillary dermis), warstwę siateczkowatą (reticular dermis) oraz warstwę śródskórnych komórek tłuszczowych (dermal white adipose tissue; dWAT) (ryc. 1). Warstwy: brodawkowata oraz siateczkowata są zbudowane z dwóch typów fibroblastów skóry charakteryzujących się odmienną ekspresję genów [17]. Ta „odmienność” przekłada się na różnice w zdolności do wytwarzania składników macierzy zewnątrzkomórkowej, podziałów komórkowych czy też kurczliwości [6,7]. Śródskórne komórki tłuszczowe budują najgłębiej położoną warstwę skóry, która od niedawna jest przedmiotem intensywnych badań $[8,9,10,11]$. Wykazano, że komórki dWAT biorą udział w procesach utrzymania homeostazy skóry, termoregulacji, cyklu wzrostu włosów i gojenia urazów.

\section{Gojenie urazów skóry z wytworzeniem blizny}

W urazach przebiegających z uszkodzeniem skóry najważniejsze jest przywrócenie jej ciągłości jako bariery ochronnej. Proces gojenia uszkodzeń skóry (ran) składa się z nakładających się na siebie etapów: odpowiedzi zapalnej
(I), migracji i proliferacji komórkowej (II) oraz przebudowy (III) $[4,12]$.

Etap I: Do miejsca urazu napływają liczne komórki układu immunologicznego m.in.: neutrofile, makrofagi, limfocyty. Rezultatem ich aktywności jest usunięcie bakterii i szczątków komórkowych w miejscu zranienia oraz uwalnianie licznych mediatorów prozapalnych i wytwarzanie cytokin - czynników, które wpływają na migrację, proliferację i aktywację wielu typów komórek.

Etap II: Odbudowa uszkodzonego naskórka rozpoczyna się już w pierwszej dobie po zranieniu. Keratynocyty warstwy podstawnej naskórka obecne na brzegu rany wydłużają się i zaczynają migrować, stopniowo pokrywając uszkodzony obszar skóry [13, 14]. Migracja komórek wymaga wydzielania licznych enzymów m.in. metaloproteinaz macierzy (MMPs).

Etap III: Stopniowo zaczyna dominować etap przebudowy blizny. Fibroblasty skóry migrujące w miejsce rany i wytwarzające składniki macierzy zewnątrzkomórkowej (w tym kolagen) przekształcają się w bardzo aktywne miofibroblasty, zdolne do obkurczania rany [15]. Początkowo rusztowanie rany stanowi kolagen typu III, następnie jest on częściowo zastępowany przez kolagen typu I. Organizacja włókien kolagenu w bliźnie pozostaje jednak inna niż w pierwotnej tkance. Metaloproteinazy macierzy, aktywne w procesie odbudowy naskórka, są również zaangażowane na tym etapie gojenia, odpowiadając m.in. za organizację włókien kolagenowych. Ostatecznie, gdy miofibroblasty stają się zbędne, są eliminowane w procesie apoptozy. Końcowym efektem naprawczego procesu gojenia urazów skóry jest blizna, której rozmiar i struktura zależy od wielu czynników, m.in. obszaru i miejsca urazu, czynników powodujących uraz, głębokości rany, ale również od osobniczego stanu fizjologicznego, a także etapu rozwoju ontogenicznego (płód, wiek dorosły, wiek starczy) [16, 17, 18]. Innym, niezwykle istotnym czynnikiem w przebiegu procesu gojenia jest hipoksja, czyli zmniejszona dostępność tlenu. Pojawia się w miejscu urazu wskutek wzmożonej aktywności komórek (m.in. stanu zapalnego) i uszkodzenia naczyń krwionośnych, zjawisk prowadzących do ograniczenia podaży tlenu z krwi [19].

Podkreślić należy, że punktem wyjścia kaskady zdarzeń prowadzącej do „zamknięcia” rany jest skoordynowana aktywność regulatorów ekspresji genów - czynników transkrypcyjnych - wśród których są m.in.: FOXN1, FOXO1 i 3, HOXA3, HOXD3, SMAD2, AP-1, OVOL 1 i OVOL 2 [12, 20, $21,22]$. Współdziałają ze sobą, aby kontrolować proliferację, różnicowanie, migrację i apoptozę komórek - procesy, które składają się na przywrócenie homeostazy w przypadku urazu oraz utrzymanie jej w warunkach fizjologicznych [12, 23, 24, $25,26]$. 
A.

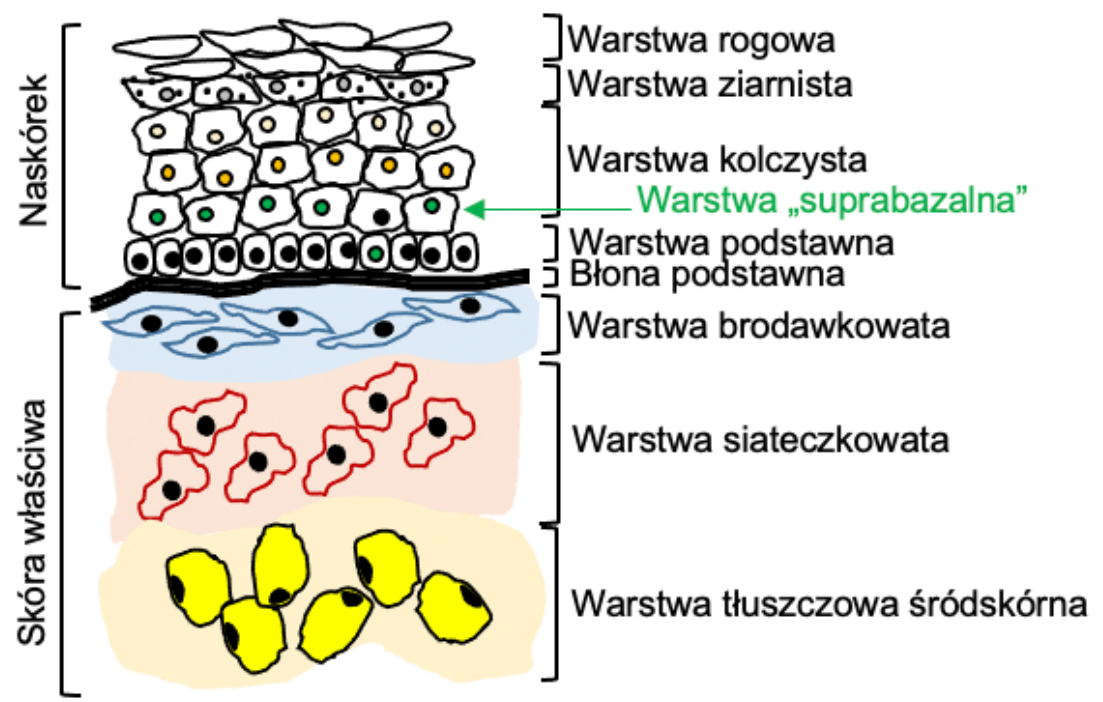

○) Keratynocyty wykazujące ekspresję Foxn1

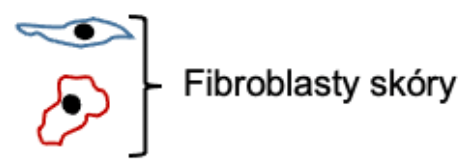

Komórki tluszczowe

B.

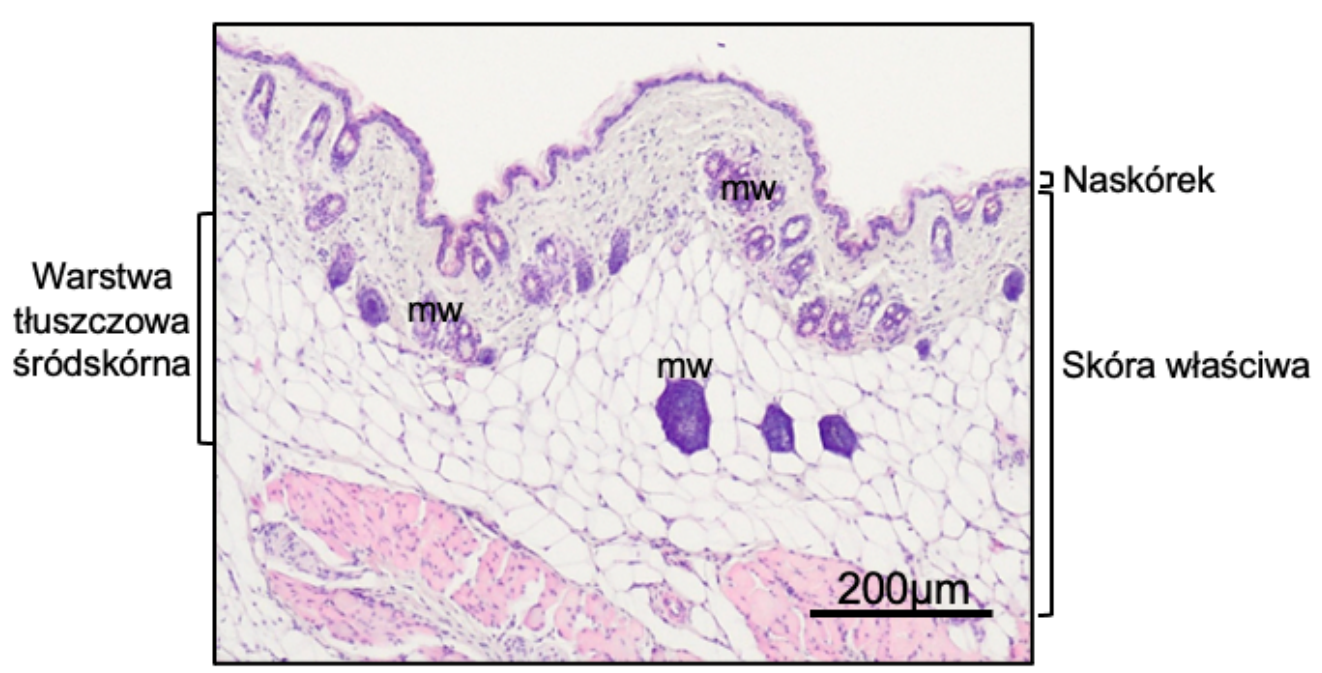

Rycina 1. A - Schemat budowy skóry; B - obraz histologiczny niezranionej, barwionej hematoksyliną i eozyną skóry myszy szczepu C57BL/6; mw- mieszki włosowe 


\section{Bezbliznowa regeneracja}

Odmiennym w porównaniu do bliznowego (naprawczego) gojenia, jest proces regeneracji. Częsta u bezkręgowców i niższych kręgowców zdolność regeneracji, u ssaków jest ewenementem. W 1979 r. Rowlatt i wsp. wykazali, że ludzkie płody są zdolne do regeneracji urazów skóry [27], jednak zdolność tą tracą $w$ trzecim trymestrze rozwoju płodowego [28]. Podobnie płody myszy i szczurów są zdolne do regeneracji urazów skóry przez pierwsze dwa trymestry, czyli odpowiednio do 16. i 18. dnia rozwoju płodowego [29]. Mimo licznych badań, które wskazują na potencjalne czynniki sprawcze tej unikatowej zdolności płodów, mechanizm regeneracji nie został w pełni poznany. Jak dotąd wykazano, że to nie środowisko, w którym rozwija się płód, lecz cechy własne (właściwości) regenerującej się skóry, determinują rezultat procesu gojenia [30]. Wspomniane właściwości to różnice na poziomie komórkowym i molekularnym, na które składają się m.in. obniżony poziom odpowiedzi immunologicznej, odmienna charakterystyka fibroblastów (np. różnice $w$ zdolności do migracji czy wytwarzania kolagenu), zmniejszony poziom TGF- $\beta 1$ i zwiększona ilość kwasu hialuronowego [31, 32].

$\mathrm{U}$ dorosłych przedstawicieli ssaków zjawisko regeneracyjnego (bezbliznowego) gojenia urazów skóry zostało opisane jedynie u dwóch reprezentantów tej gromady: myszy pozbawionych aktywności czynnika transkrypcyjnego FOXN1 (myszy Foxn1 ${ }^{-\digamma}$ ) [33, 34, 35] oraz kolcomyszy (Acomys) [36, 37].

\section{Myszy pozbawione czynnika transkrypcyjnego FOXN1(Foxn1 ${ }^{-l-}$ )}

Czynnik transkrypcyjny FOXN1 ulega ekspresji wyłącznie w nabłonkach: grasicy oraz skóry [38, 39]. Brak jego aktywności u myszy skutkuje brakiem grasicy (athymic mouse) oraz związanym z tym niedoborem odporności (brak limfocytów T), a także brakiem włosów wyrastających ponad powierzchnię skóry (fenotypowo myszy nagie; nude) [40]. Myszy nagie powstałe w wyniku spontanicznej mutacji w genie kodującym czynnik transkrypcyjny FOXN1 (mutacja ta prowadzi do przedwczesnej terminacji translacji i powstania nieaktywnego białka) są znane już od $1966 \mathrm{r}$. i powszechnie stosowane $w$ badaniach biomedycznych m.in. nad nowotworami [41]. Brak grasicy oraz limfocytów T, czyli brak odpowiedzi immunologicznej, spowodował, że myszy Foxn1- stały się eksperymentalnym modelem dla przeszczepianych ludzkich komórek nowotworowych [42].

Natomiast zdolność myszy Foxn1-- do regeneracyjnego gojenia urazów jest przedmiotem badań od niedawna. Dotychczas wykazano, że ani brak grasicy, ani też niedobór odporności nie są wystarczającymi warunkami sprzyjającymi regeneracji [35]. Wskazano również, że czynnik transkrypcyjny FOXN1 jest włączony $w$ proces gojenia bliznowego (naprawczego), gdyż bierze udział $\mathrm{w}$ reepitelializacji (odbudowie naskórka) i EMT - procesach odpowiedzialnych za wytworzenie pourazowej blizny, a także w regulacji dWAT $[10,20,43]$. Zatem przyczyną unikatowej zdolności myszy Foxn1-- do gojenia bezbliznowego może być brak aktywnego FOXN1 [35, 44].

\section{Lokalizacja ekspresji i funkcja FOXN1 w skórze}

Lokalizacja ekspresji FOXN1 w skórze jest ograniczona do naskórka i mieszków włosowych (ryc 2). W naskórku międzymieszkowym (interfollicular epidermis) FOXN1 występuje wyłącznie w populacji pierwszej warstwy komórek kolczystych przyległych bezpośrednio do warstwy podstawnej (warstwa przypodstawna; suprabasal) oraz pojedynczych komórek warstwy podstawnej (bazalnej; basal) (ryc. 1) [20, 43, 45].

Umiejscowienie w warstwie przypodstawnej, czyli w miejscu wczesnych etapów terminalnego różnicowania keratynocytów, koreluje $z$ wykazaną rolą czynnika transkrypcyjnego FOXN1 jako czynnika stymulującego przejście keratynocytów ze stadium proliferacji do stadium postmitotycznego różnicowania [45, 46, 47, 48]. Keratynocyty, wędrując $z$ najgłębiej położonych warstw naskórka: podstawnej i przypodstawnej, przestają wykazywać ekspresję FOXN1 [46, 47, 48]. Dowiedziono, że dodatek $\mathrm{Ca}^{2+}$ (induktor różnicowania komórek in vitro) do medium hodowlanego prowadzi do wyraźnej stymulacji ekspresji FOXN1 w keratynocytach. Jednocześnie Li i wsp. (2007 r.) wykazali wzrost ekspresji markerów późnych etapów różnicowania: inwolukryny i filagryny oraz spadek ekspresji markerów wczesnych etapów różnicowania (keratyny 10) w keratynocytach izolowanych z myszy Foxn $1^{-1-}$ hodowanych in vitro [49]. W ścieżkach sygnałowych, na drodze których FOXN1 kontroluje różnicowanie komórek, uczestniczą: PKC, PI3K i AKT [49, 50, 51, 52, 53]. Wykazano także, że FOXN1 jest zaangażowany $w$ proces pigmentacji. Stymuluje wydzielanie FGF2 biorąc udział $w$ komunikacji między keratynocytami i melanocytami [54]. Jako czynnik transkrypcyjny FOXN1 bezpośrednio reguluje transkrypcję keratyn $\mathrm{mHa}$ i $\mathrm{mHa} 5[55,56]$.

Podobnie jak inni członkowie rodziny czynników transkrypcyjnych z motywem forkhead/helix winged, FOXN1 zawiera wysoce konserwatywną domenę wiążącą DNA, której sekwencja aminokwasowa wykazuje co najmniej $80 \%$ homologii wśród odległych przedstawicieli Metazoa, w tym ludzi [57]. Przypadki fenotypu "nude” u ludzi są niezwykle rzadkie. Doniesienia pochodzące z Włoch (1996 r.) opisuja 

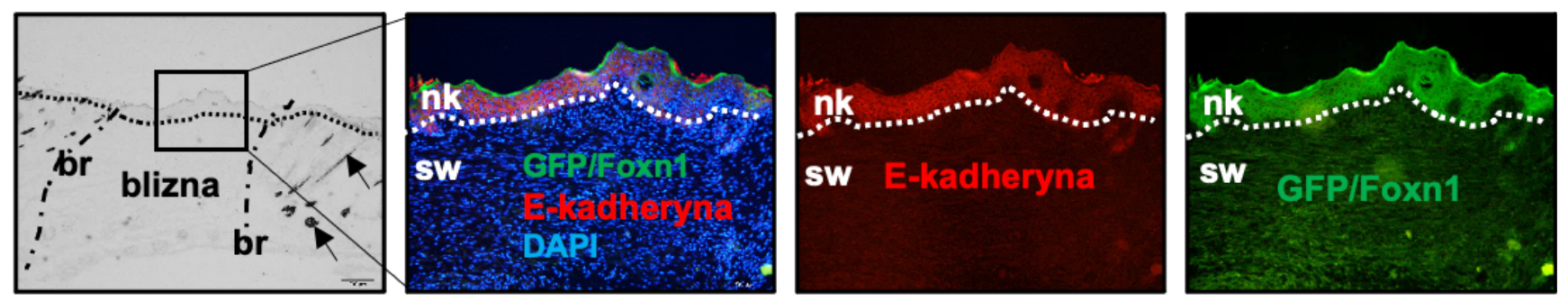

Rycina 2: Obraz histologiczny pourazowej skóry (dzień 6 po zranieniu). Immunofluorescencyjna detekcja E-kadheryny w pourazowej skórze myszy transgenicznych Foxn1: eGFP. br- brzeg rany, nk- naskórek, sw-skóra właściwa, strzałki wskazują mieszki włosowe, linia przerywana oddziela naskórek od skóry właściwej

przypadek dwóch sióstr, u których stwierdzono fenotyp nude/ SCID spowodowany brakiem aktywnego czynnika FOXN1 [58]. Konsekwencje braku aktywnego FOXN1 u myszy i ludzi są zbliżone. Należą do nich zaburzenia: keratynizacji, rozwoju mieszków włosowych oraz rozwoju grasicy i związany z tym niedobór limfocytów T [58, 59]. Biorąc powyższe pod uwagę, badania dotyczące FOXN1 prowadzone na modelu mysim mogą bezpośrednio przełożyć się na wiedzę o funkcji tego czynnika transkrypcyjnego u ludzi.

\section{FOXN1 jako regulator bliznowego vs bezbliznowego gojenia urazów skóry}

Lee i wsp. (1999 r.) wykazali, że ekspresja FOXN1 w skórze rozpoczyna się u myszy od okolic nosa i pyszczka w 14. dniu rozwoju płodowego i rozszerza się do całej skóry w 16.17. dniu rozwoju płodowego [45]. Zatem utrata zdolności do regeneracji urazów skóry u płodów myszy zbiega się z czasem, w którym uaktywnia się ekspresja czynnika transkrypcyjnego FOXN1 [29, 45]. Co niezwykle istotne, brak aktywności FOXN1 jest wspólną właściwością płodów (przez dwa pierwsze trymestry) i zdolnych do regeneracji urazów skóry myszy nagich (Foxn1-l-). Nasuwają się więc pytania: o znaczenie braku aktywności FOXN1, podobieństwa w ekspresji genów komórek budujących skórę myszy zdolnych do regeneracji i ich powiązanie z FOXN1. W odpowiedzi na postawione pytania przeprowadzono porównanie profili transkryptomicznych metodą sekwencjonowania nowej generacji SOLiD [60]. W doświadczeniach wykorzystano dwa modele regeneracyjnego gojenia urazów skórnych, które łączy brak ekspresji FOXN1: płody myszy w 14. dniu rozwoju (E14 - etap rozwoju charakteryzujący się bezbliznowym gojeniem urazów skóry i brakiem ekspresji FOXN1) oraz dorosłe myszy nagie (Foxn1\%). Modelem przeciwstawnym, czyli modelem gojenia urazów skóry w sposób bliznowy (reperacyjny), były mysie płody w 18. dniu rozwoju (E18 etap rozwoju charakteryzujący się bliznowym gojeniem urazów skóry i ekspresją FOXN1) oraz dorosłe myszy $\left(\right.$ Foxn $\left.1^{+/+}\right)$. Badania przeprowadzono na myszach o wspólnym podłożu genetycznym (szczep C57BL/6) [60]. Celem takiego postępowania było wykluczenie potencjalnych różnic w ekspresji genów, a w związku z tym różnic w przebiegu naprawczego/bliznowego procesu gojenia wynikających jedynie ze zróżnicowania między szczepami. Analiza wyników wykazała, że dwa unikatowe modele regeneracyjnego gojenia urazów skóry: myszy Foxn1-/- i płody myszy (E14) charakteryzują się podobnymi profilami transkryptomicznymi. Myszy Foxn1-- i mysie płody E14 łączy zmieniony profil ekspresji genów skóry związanych z przebudową tkanek, budową cytoszkieletu, gojeniem urazów, odpowiedzią immunologiczną i różnicowaniem [60]. Te charakterystyczne zmiany w profilu ekspresji określonych grup (klastrów) genów tworzą „sygnaturę regeneracji”, która może być pośrednim lub bezpośrednim następstwem braku aktywnego FOXN1. Ważne jest to, że wyłonione w analizie porównania profili transkryptomicznych grupy genów o zbliżonych funkcjach, podobnie jak kierunek regulacji genów w tych grupach (stymulacja lub supresja), są wspólne i zgodne nie tylko dla myszy Foxn1/- i E14, ale również innych modeli zwierząt zdolnych do regeneracji, np. niższych kręgowców [61] czy myszy MRL [62].

W analizie transkryptomów skóry wśród genów o obniżonym poziomie ekspresji jednocześnie u myszy nagich i E14 znalazły się geny: Hox, Pax1, Six1, Six2, Pknox1 kodujące białka kluczowe w specyfikacji losu komórek podczas rozwoju embrionalnego i promujące różnicowanie komórek macierzystych [60]. Wyniki te wskazują, że FOXN1 nie tylko reguluje równowagę między proliferacją i różnicowaniem, ale też kontroluje program rozwoju i dojrzewania skóry. Unikatowa charakterystyka „niedojrzałej, zatrzymanej w rozwoju” skóry dorosłych myszy Foxn1/- czyni ją zbliżoną do skóry mysich płodów E14 i jest przykładem neotenii wśród ssaków. Można zatem wnioskować, że skutki braku aktywnego FOXN1 tworzą niszę sprzyjającą regeneracji. Ponadto uzyskane dane sugerują również, że czynnik transkrypcyjny FOXN1 uczestniczy w „dialogu” ze szlakami sygnałowymi WNT, BMP, $\mathrm{NOTCH}$ [60], co zostało potwierdzone w badaniach in vivo 
[63]. Komórki naskórka myszy Foxn1-eGFP wykazywały kolokalizację z WNT11, który jest elementem szlaku zaangażowanego $\mathrm{w}$ regulację ekspresji FOXN1 w grasicy. Wskazuje to na udział szlaku WNT w regulacji FOXN1 również w skórze [63].

Pomimo że FOXN1 ulega ekspresji wyłącznie w keratynocytach (komórkach budujących naskórek) w sposób pośredni wpływa także na własności fibroblastów skóry (FS) - komórek skóry właściwej [34, 64, 65]. Wyniki te potwierdziła analiza fenotypowa FS izolowanych z myszy Foxn1-1-, która wykazała wyższy niż w przypadku FS izolowanych ze skóry myszy kontrolnych procentowy udział populacji komórek o charakterze komórek macierzystych (progenitorowych), wykazujących ekspresję markerów OCT4, CD73 oraz CD117 [65]. Ponadto FS izolowane ze skóry myszy pozbawionych Foxn1 $^{-1}$ charakteryzowały się większą plastycznością (łatwością w różnicowaniu się do komórek tłuszczowych), jak również wzmożoną wrażliwością na stymulację TGF-ß3 [64]. Kompleksowo wyniki te wykazały, że FOXN1 to niezwykle istotny czynnik transkrypcyjny, którego aktywność lub jej brak determinuje dojrzewanie skóry, jej homeostazę oraz przebieg procesu gojenia urazów skórnych: reperacyjny vs regeneracyjny.

\section{Mechanizm regulacji FOXN1}

Niewiele wiadomo o genach regulowanych przez FOXN1, a jeszcze skromniejsza jest wiedza dotycząca regulacji samego czynnika FOXN1. Przeprowadzone serie doświadczeń z wykorzystaniem hodowli keratynocytów oraz ich transdukcji adenowirusem wyposażonym w cDNA Foxn1 (Ad-Foxn1) przyniosły nowe, ważne wyniki wskazujące na udział FOXN1 w regulacji równowagi między ekspresją białek pro- i antyapoptotycznych [53], (tabela 1). Analiza porównawcza profili białkowych keratynocytów transdukowanych adenowirusem zawierającym sekwencję Foxn1 (Ad-Foxn1) lub Ad-GFP (wirus kontrolny, zawierający cDNA białka zielonej fluorescencji) wykazała, że nadekspresja FOXN1 zwiększa ilość głównie białek promujących apoptozę; P4HB, CTSD, LGALS7, VDAC1. Analiza fenotypu komórek transdukowanych Ad-Foxn1 lub Ad-GFP przeprowadzona z zastosowaniem cytometrii przepływowej potwierdziła zwiększony udział komórek apoptotycznych w puli komórek o podwyższonej ekspresji FOXN1. Jednak analiza proteomiczna wykazała jednoczesny wzrost poziomu białka TXN (stymulowanego obecnością Ad-Foxn1), które chroni komórkę przed działaniem wolnych rodników i wykazuje działanie antyapoptotyczne. FOXN1 stymulował również

Tabela 1. Główne grupy białek regulowanych poziomem FOXN1 w keratynocytach skóry myszy C57BL/6 (B6) transdukowanych wektorem adenowirusowym obarczonym transgenem Foxn1 (nadekspresja FOXN1) oraz wektorem kontrolnym/pustym (ekspresja endogennego Foxn1). Zestawienie opracowane na podstawie analizy proteomicznej wykonanej metodą 2D-DIGE [53]

\begin{tabular}{|c|c|c|c|c|}
\hline & \multicolumn{4}{|c|}{ Białka regulowane poziomem FOXN1 } \\
\hline & Antyapoptotyczne & Proapoptotyczne & $\begin{array}{c}\text { Związane z odpowiedzią na } \\
\text { hipoksję }\end{array}$ & $\begin{array}{l}\text { Charakterystyczne dla wa- } \\
\text { runków normoksji }\end{array}$ \\
\hline \multirow[t]{3}{*}{$\begin{array}{l}\text { Komórki z nadekspresją } \\
\text { FOXN1 }\end{array}$} & $\begin{array}{c}\text { HSP70 } \\
\text { (białko szoku cieplnego) }\end{array}$ & $\begin{array}{c}\text { CTSD } \\
\text { (prekursor katepsyny D) }\end{array}$ & $\begin{array}{c}\text { HSP70 } \\
\text { (białko szoku cieplnego) }\end{array}$ & $\begin{array}{c}\text { ACO2 } \\
\text { (akonitaza 2) }\end{array}$ \\
\hline & $\begin{array}{c}\text { TXN } \\
\text { (tioredoksyna) }\end{array}$ & $\begin{array}{l}\text { LGALS7 (galektyna-7) } \\
\text { P4HB } \\
\text { (4-hydroksylaza pro- } \\
\text { lilowa, beta polipeptyd, } \\
\text { izoforma CRA) }\end{array}$ & $\begin{array}{c}\text { TXN } \\
\text { (tioredoksyna) }\end{array}$ & $\begin{array}{c}\text { ECHS } \\
\text { (hydrataza enoilo-CoA, prekur- } \\
\text { sor mitochondriów) } \\
\text { CTSD } \\
\text { (prekursor katepsyny D) }\end{array}$ \\
\hline & & $\begin{array}{c}\text { VDAC1 } \\
\text { (białko } 1 \text { kanału } \\
\text { o selektywności anion- } \\
\text { owej) }\end{array}$ & & $\begin{array}{c}\text { P4HB } \\
\text { (4-hydroksylaza prolilowa, beta } \\
\text { polipeptyd, izoforma CRA) }\end{array}$ \\
\hline $\begin{array}{c}\text { Komórki } \\
\text { z fizjologicznym } \\
\text { (endogennym) } \\
\text { poziomem FOXN1 }\end{array}$ & $\begin{array}{c}\text { HSP27 } \\
\text { (białko szoku cieplnego) } \\
\text { HSP90 } \\
\text { (białko szoku cieplnego) }\end{array}$ & & $\begin{array}{c}\text { HSP27 } \\
\text { (białko szoku cieplnego) } \\
\text { HSP90 } \\
\text { (białko szoku cieplnego) }\end{array}$ & \\
\hline \multirow{2}{*}{ poziomem FOXN1 } & $\begin{array}{c}\text { PDPK1 } \\
\text { (kinaza zależna od fosfoino- } \\
\text { zytydu-1) }\end{array}$ & & $\begin{array}{c}\text { PGD } \\
\text { (dehydrogenaza 6-fosfogluko- } \\
\text { nianowa, dekarboksylująca) }\end{array}$ & \\
\hline & & & $\begin{array}{c}\text { PGAM1 } \\
\text { (mutaza fosfoglicerynianowa 1) }\end{array}$ & \\
\hline
\end{tabular}


wzrost poziomu ekspresji białka szoku cieplnego HSP70, również wykazującego działanie antyapoptotyczne [53]. Zatem można założyć, że funkcja FOXN1 jest bilateralna bierze on udział w utrzymaniu zrównoważonych poziomów białek pro- $\mathrm{i}$ antyapoptotycznych.

Jednym $z$ istotniejszych wyników porównania proteomów keratynocytów transdukowanych Ad-Foxn1 lub Ad-GFP było wykazanie różnic $w$ obecności oraz poziomie białek związanych z odpowiedzią komórek na hipoksję [53] (tabela 1). Wśród nich można wymienić TXN (silnie stymuluje ścieżki sygnałowe zależne od HIF1a) oraz HSP70, których obecność pozytywnie koreluje ze wzrostem poziomu ekspresji FOXN1. Keratynocyty o zwiększonej ekspresji FOXN1 charakteryzuje podwyższony poziom TXN i HSP70, natomiast w komórkach tych wykazano również zwiększone poziomy białek typowych dla warunków normoksji, takich jak: CTSD, ACO2, P4HB, ECHS1. Wskazuje to, podobnie jak w przypadku zjawiska apoptozy, na dwukierunkową rolę FOXN1 w regulacji białek kluczowych dla przetrwania komórek w zmiennych warunkach dostępności tlenu. Uzyskane wyniki wnoszą nową, istotną wiedzę o roli FOXN1 jako stymulatora szlaków komórkowych, wskazują na jego potencjalne geny docelowe, a także pośrednio sugerują możliwość regulacji ekspresji czynnika FOXN1 dostępnością tlenu. W systemie in vitro, wykorzystując dwa modele komórek: keratynocyty izolowane z myszy kontrolnych (endogennie aktywny FOXN1) oraz keratynocyty izolowane z myszy Foxn $1^{-1}$, transdukowanych Ad-Foxn1 (ekspresja i aktywność FOXN1 egzogenna), wykazano, że warunki zmniejszonej dostępności tlenu (hipoksja; $1 \% \mathrm{O}_{2}$ ) prowadzą do gwałtownej indukcji ekspresji zarówno endogennego (keratynocyty myszy kontrolnych), jak i egzogennego (keratynocyty myszy nagich transdukowane Ad-Foxn1) FOXN1 [53]. Zatem, jeżeli niewielka dostępność tlenu w warunkach in vitro stymuluje ekspresję FOXN1, czy obserwowane $w$ warunkach in vivo $w$ trakcie procesu gojenia urazów skóry zjawisko hipoksji może angażować czynnik FOXN1?

\section{FOXN1 w procesie gojenia urazów skóry}

Udział FOXN1 w procesie bliznowego gojenia urazów skóry wykazano na modelu myszy transgenicznych, u których jeden allel genu Foxn1 został sprzężony z genem GFP (myszy Foxn1::eGFP) [20, 43, 53, 63]. Model ten umożliwił analizę ekspresji Foxn1 uwidocznioną przez obecność białka GFP w tkance (ryc. 2). Analiza skrawków pourazowej skóry myszy Foxn1::eGFP wykazała wysoki poziom ekspresji GFP w warstwie brzeżnej zranionego naskórka [20]. Nowo odtworzony, migrujący, a następnie proliferujący naskórek stopniowo pokrywający ranę również wykazywał silną ekspresję GFP, która dodatkowo kolokalizowała z keratyną
16, markerem aktywowanych keratynocytów [20] oraz E-kadheryną, markerem naskórka/keratynocytów (ryc. 2) [20]. Ponadto wzór ekspresji Foxn1-eGFP w tkankach pourazowych skóry korelował ze zmianami w ekspresji MMP9, enzymu zaangażowanego w proces gojenia urazów skóry $[20,43]$. Intensywne badania nad interakcją między FOXN1, a MMP-9 wskazały na stymulację obu czynników przez hipoksję, natomiast mechanizm regulacji MMP-9 zależny od czynnika FOXN1 oczekuje na ostateczne wyjaśnienie [53].

Wykazany w badaniach in vitro pośredni wpływ FOXN1 na FS został potwierdzony w badaniach in vivo. W preparacie skóry myszy Foxn1::eGFP w 4.-5. dniu po urazie zaobserwowano silną fluorescencję pochodzącą od GFP (wskazującą na jednoczesną ekspresję FOXN1) w warstwie skóry właściwej [20]. Sygnał był umiejscowiony w FS, które jednocześnie z eGFP/FOXN1 wykazywały obecność białka SNAIL1 będącego markerem EMT procesu zaangażowanego w tworzenie blizny. Wyniki potwierdziła analiza fenotypowa komórek skóry, która wykazała obecność w pourazowej skórze właściwej oprócz komórek o cechach mezenchymalnych (fibroblastów) również komórek pochodzenia naskórkowego (wyznakowanych GFP) [20]. Kolejnego dowodu wskazującego na znaczenie FOXN1 w procesie gojenia dostarczyła analiza tego procesu u zwierząt w różnym wieku (2, 6 i 18 miesięcy). Umożliwiła wykazanie wzrostu ekspresji mRNA FOXN1 w fazie remodelingu (dni pourazowe 14-21) niezależnie od długości życia badanych zwierząt. Reakcje immunofluorescencyjne pourazowych tkanek w dniach 14-21 wykazały obecność w warstwie skóry właściwej komórek kolokalizujących, z jednoczesną obecnością białka zielonej fluorescencji (GFP/FOXN1) oraz markera miofibroblastów (aSMA) [43].

\section{FOXN1 w regulacji śródskórnej warstwy tłuszczowej}

Istotnym i niedawno zaobserwowanym zjawiskiem jest potencjalny udział czynnika FOXN1 w kształtowaniu podatności na indukowaną dietą otyłość $[10,66]$. Wykazano, że myszy Foxn1/- w warunkach neutralnej temperatury otoczenia karmione dietą wysokotłuszczową nie przybierają na wadze tak jak myszy kontrolne $\left(F o x n 1^{+/+}\right)$[66]. Podobnie myszy o obniżonej ekspresji genu FOXN1 $\left(\right.$ Foxn1 $\left.{ }^{+-}\right)$są mniej podatne na otyłość [10]. Analiza niezranionych oraz pourazowych tkanek skórnych myszy Foxn1+- wykazała zmienione w porównaniu do tkanek myszy kontrolnych $\left(\right.$ Foxn $1^{+/+}$) profile ekspresji regulatorów zaangażowanych w proces adipogenezy: Ppary, Fabp4 oraz leptyny [10]. Śródskórna tkanka tłuszczowa (dWAT), która jest zaangażowana w utrzymanie homeostazy skóry, regulację odpowiedzi immunologicznej, a także proces gojenia ran, 
regulowana jest proadipogenicznymi szlakami, w których udział biorą BMP2 i IGF2 [67]. Zaobserwowano, że w skórze myszy stopniowej inaktywacji czynnika FOXN1 (myszy o fenotypie Foxn1 $1^{+/+}$, Foxn1 ${ }^{+/-}$, Foxn1 $1^{-/-}$) towarzyszy stopniowy spadek ekspresji Bmp2 i lgf2. Wskazuje to na zależność procesu adipogenezy w dWAT od ekspresji czynnika FOXN1, a w konsekwencji udział FOXN1 w gojeniu ran. Ponadto analiza składu lipidowego skóry myszy Foxn1-l-i Foxn1 $1^{+/+}$ wykazała istotnie różnice [68]. Jednak wskazanie głównych elementów szlaków sygnałowych czynnika transkrypcyjnego FOXN1 zaangażowanych w proces adipogenezy śródskórnej warstwy tłuszczowej wymaga dalszych, wnikliwych badań.

\section{Podsumowanie}

Czynnik transkrypcyjny FOXN1 reguluje rozwój i dojrzewanie skóry, odpowiada za ciągłą odnowę naskórka, a także zaangażowany jest w proces bliznowego gojenia urazów skóry. Brak aktywności FOXN1 w okresie życia płodowego powoduje zachowanie cech embrionalnych skóry w trakcie życia dorosłego (zjawisko neotenii).

Podobieństwo transkryptomów skóry myszy regenerujących urazy skórne (płodów myszy i dorosłych myszy nagich) oraz porównanie ich do profili transkryptomicznych skóry myszy gojących urazy skórne w procesie bliznowym/ naprawczym, wskazuje na FOXN1 jako główny element szlaku sygnałowego regulującego przejście między gojeniem regeneracyjnym (bezbliznowym) a reperacyjnym (bliznowym). Uwzględniając to, że lokalizacja i modulacja ekspresji czynnika FOXN1 w skórze myszy jest analogiczna z ekspresją w skórze człowieka oraz że fenotyp nieaktywnego czynnika FOXN1 występuje również u ludzi, rozpoznanie ścieżek sygnałowych - w tym genów docelowych czynnika FOXN1 - może pozwolić na ukierunkowanie procesu gojenia urazów skóry na bezbliznową regenerację.

\section{Wykaz skrótów}

ACO2 - akonitaza 2 (aconitase 2), Ad-Foxn1 - wektor adenowirusowy $\mathrm{z}$ insertem Foxn1, Ad-GFP - wektor adenowirusowy $z$ insertem GFP (białko zielonej fluoroscencji; green fluorescent protein), AKT - kinaza białkowa B (protein kinase B), BMP2 - białko morfogenetyczne kości 2 (bone morphogenetic protein 2), CD117-kompleks różnicowania 117 (cluster of differentiation 117), CD73 - kompleks różnicowania 73 (cluster of differentiation 73), CTSD - prekursor katepsyny D (cathepsin D), dWAT - śródskórne komórki tłuszczowe (dermal white adipose tissue), ECHS1 - hydrataza enoiloCoA, prekursor mitochondriów (enoyl Co enzyme A hydratase, short chain, 1), EMT - przejście epitelialno-mesenchymalne (epithelial-mesenchymal transition), FABP4 - białko wiążące kwasy tłuszczowe 4 (fatty acid binding protein 4), FGF2 czynnik wzrostu fibroblastów 2 (fibroblast growth factor 2), FOXN1 - czynnik transkrypcyjny FOXN1 (forkhead box N1), FOXO1 - czynnik transkrypcyjny FOXO1 (forkhead box O1), FOXO3 - czynnik transkrypcyjny FOXO3 (forkhead box O3), HIF1a - czynnik indukowany hipoksją 1a (hypoxia-inducible factor 1a), HOXA3 - czynnik transkrypcyjny homeobox A3 (homeobox Hox-A3), HOXD3 - czynnik transkrypcyjny D3 (homeobox Hox-D3), HSP27 - białko szoku cieplnego małe (heat shock protein 27), HSP70 - białko szoku cieplnego średniocząsteczkowe (heat shock protein 70), HSP90 - białko szoku cieplnego małocząsteczkowe (heat shock protein 90), IGF2 - insulinopodobny czynnik wzrostu 2 (insulin-like growth factor 2), LGALS7 - galektyna-7 (galectin-7), mHa3 - mysia keratyna (murine hair keratin 3), mHa5 - mysia keratyna (murine hair keratin 5), MMPs - metaloproteinazy macierzy pozakomórkowej (matrix metalloproteinase), OCT4 - czynnik transkrypcyjny OCT4 (octamer-binding transcription factor 4), OVOL1 - czynnik transkrypcyjny OVOL1 (Ovo Like Transcriptional Repressor 1), OVOL2 czynnik transkrypcyjny OVOL2 (Ovo Like Transcriptional Repressor 2), P4HB-4 - hydroksylaza prolilowa, beta polipeptyd, izoforma CRA (prolyl 4-hydroxylase subunit beta), PAX1 - czynnik transkrypcyjny PAX1 (Paired box protein PAX1), PDPK1 - kinaza zależna od fosfoinozytydu-1 (3-phosphoinositide dependent protein kinase 1), PGAM1 - mutaza fosfoglicerynianowa 1 (phosphoglycerate mutase 1), PGD - dehydrogenaza 6- fosfoglukonianowa, dekarboksylująca (phosphogluconate ehydrogenase), PI3K - 3-kinaza fosfatydyloinozytolu (phosphoinositide 3-kinase), PKC - kinaza białkowa C (protein kinase C), PKNOX1 - białko homeoboksowe PKNOX1 (homeobox protein PKNOX1), PPARY - receptor gamma aktywowany przez proliferator peroksysomów (peroxisome proliferatoractivated receptor gamma), SCID - ciężki złożony niedobór odporności (severe combined immunodeficiency), SIX1 białko homeoboksowe SIX1 (sineoculis homeobox homolog 1), SIX2 - białko homeoboksowe SIX2 (sineoculis homeobox homolog 2), SMAD2 - białko z rodziny SMAD (mothers against decapentaplegic homolog 2), SNAILI - czynnik transkrypcyjny SNAILI (Snail family transcriptional repressor 1), TCF/LEF - czynniki transkrypcyjne TCF/LEF (T-cell factor/ lymphoid-enhancing factor), TGF $\beta$ - transformujący czynnik wzrostu $\beta$ (transforming growth factor $\beta$ ), TXN - tioredoksyna (thioredoxin), VDAC1 - białko 1 kanału o selektywności anionowej (voltage-dependent anion-selective channel 1), WNT11 - białko rodziny WNT (Wnt family member 11), aSMA - aktyna mięśni gładkich (a smooth muscle actin). 


\section{Finansowanie}

Narodowe Centrum Nauki; Projekt OPUS 14 Nr 2017/27/B/ $\mathrm{NZ} 5 / 02610$

\section{Konflikt interesów}

Autorki deklarują brak potencjalnych konfliktów interesów.

\section{Piśmiennictwo}

[1] Slominski A.T., Manna P.R., Tuckey R.C.: On the role of skin in the regulation of local and systemic steroidogenic activities. Steroids, 2015; 103: 72-88

[2] Slominski A.T., Zmijewski M.A., Skobowiat C., Zbytek B., Slominski R.M., Steketee J.D.: Sensing the environment: Regulation of local and global homeostasis by the skin's neuroendocrine system. Adv. Anat. Embryol. Cell Biol., 2012; 212: 1-115

[3] Dai X., Segre J.A.: Transcriptional control of epidermal specification and differentiation. Curr. Opin. Genet. Dev., 2004; 14: 485-491

[4] Clark R.A.: Wound repair: Overview and general considerations. W: Clark R.A.F. (red.): The Molecular, Cellular Biology of Wound Repair, red.: R.A. Clark. Plenum Press, New York, 1996: 3-35

[5] Driskell R.R., Lichtenberger B.M., Hoste E., Kretzschmar K., Simons B.D., Charalambous M., Ferron S.R., Herault Y., Pavlovic G., Ferguson-Smith A.C., Watt F.M.: Distinct fibroblast lineages determine dermal architecture in skin development and repair. Nature, 2013; 504: 277-281

[6] Marsh E., Gonzalez D.G., Lathrop E.A., Boucher J., Greco V.: Positional stability and membrane occupancy define skin fibroblast homeostasis in vivo. Cell, 2018; 175: 1620-1633.e13

[7] Rinkevich Y., Walmsley G.G., Hu M.S., Maan Z.N., Newman A.M., Drukker M., Januszyk M., Krampitz G.W., Gurtner G.C., Lorenz H.P. i wsp.: Skin fibrosis. Identification and isolation of a dermal lineage with intrinsic fibrogenic potential. Science, 2015; 348: aaa2151

[8] Driskell R.R., Jahoda C.A., Chuong C.M., Watt F.M., Horsley V.: Defining dermal adipose tissue. Exp. Dermatol., 2014; 23: 629631

[9] Schmidt B.A., Horsley V.: Intradermal adipocytes mediate fibroblast recruitment during skin wound healing. Development, 2013; 140: $1517-1527$

[10] Walendzik K., Kopcewicz M., Bukowska J., Panasiewicz G., Szafranska B., Gawronska-Kozak B.: The transcription factor FOXN1 regulates skin adipogenesis and affects susceptibility to diet-induced obesity. J. Invest. Dermatol., 2020; 140: 1166-1175.e9

[11] Wojciechowicz K., Gledhill K., Ambler C.A., Manning C.B., Jahoda C.A.: Development of the mouse dermal adipose layer occurs independently of subcutaneous adipose tissue and is marked by restricted early expression of FABP4. PLoS One, 2013; 8: e59811
[12] Schäfer M., Werner S.: Transcriptional control of wound repair. Annu. Rev. Cell. Dev. Biol., 2007; 23: 69-92

[13] Arnoux V., Côme C., Kusewitt D.F., Hudson L.G., Savagner P.: Cutaneous wound reepithelialization. W: Rise and Fall of Epithelial Phenotype. Molecular Biology Intelligence Unit, red.: P. Savanger. Springer, Boston (MA) 2005, 111-134

[14] Safferling K., Sütterlin T., Westphal K., Ernst C., Breuhahn K., James M., Jäger D., Halama N., Grabe N.: Wound healing revised: A novel reepithelialization mechanism revealed by in vitro and in silico models. J. Cell Biol., 2013; 203: 691-709

[15] Chaponnier C., Desmoulière A., Gabbiani G.: Tissue Repair, Contraction and the Myofibroblast. Biotechnology Intelligence Unit. Springer, Boston (MA) 2006

[16] Gurtner G.C., Werner S., Barrandon Y., Longaker M.T.: Wound repair and regeneration. Nature, 2008; 453: 314-321

[17] Singer A.J., Clark R.A.: Cutaneous wound healing. N. Engl. J. Med., 1999; 341: 738-746

[18] Werner S., Grose R.: Regulation of wound healing by growth factors and cytokines. Physiol. Rev., 2003; 83: 835-870

[19] Lokmic Z., Musyoka J., Hewitson T.D., Darby I.A.: Hypoxia and hypoxia signaling in tissue repair and fibrosis. Int. Rev. Cell Mol. Biol., 2012; 296: 139-185

[20] Gawronska-Kozak B., Grabowska A., Kur-Piotrowska A., Kopcewicz M.: Foxn1 transcription factor regulates wound healing of skin through promoting epithelial-mesenchymal transition. PLoS One, 2016; 11: e0150635

[21] Haensel D., Sun P., MacLean A.L., Ma X., Zhou Y., Stemmler M.P., Brabletz S., Berx G., Plikus M.V., Nie Q., Brabletz T., Dai $X .:$ An Ovol2-Zeb1 transcriptional circuit regulates epithelial directional migration and proliferation. EMBO Rep., 2019; 20: e46273

[22] Rajendran N.K., Dhilip Kumar S.S., Houreld N.N., Abrahamse $\mathrm{H}$.: Understanding the perspectives of forkhead transcription factors in delayed wound healing. J. Cell Commun. Signal., 2019; 13: 151-162

[23] Bellavia G., Fasanaro P., Melchionna R., Capogrossi M.C., Napolitano M.: Transcriptional control of skin reepithelialization. J. Dermatol. Sci., 2014; 73: 3-9

[24] Lee B., Villarreal-Ponce A., Fallahi M., Ovadia J., Sun P., Yu Q.C., Ito S., Sinha S., Nie Q., Dai X.: Transcriptional mechanisms link epithelial plasticity to adhesion and differentiation of epidermal progenitor cells. Dev. Cell, 2014; 29: 47-58

[25] Mori R., Tanaka K., de Kerckhove M., Okamoto M., Kashiyama K., Tanaka K., Kim S., Kawata T., Komatsu T., Park S. i wsp.: Reduced FOXO1 expression accelerates skin wound healing and attenuates scarring. Am. J. Pathol., 2014; 184: 2465-2479

[26] Teng A., Nair M., Wells J., Segre J.A., Dai X.: Strain-dependent perinatal lethality of Ovol1-deficient mice and identification of Ovol2 as a downstream target of Ovol1 in skin epidermis. Biochim. Biophys. Acta, 2007; 1772: 89-95

[27] Rowlatt U.: Cleft lip and palate associated with amniotic band limb amputations in a 20 week human fetus. Cleft. Palate. J., 1979; 16: 206-209 
[28] Lorenz H.P., Longaker M.T., Perkocha L.A., Jennings R.W., Harrison M.R., Adzick N.S.: Scarless wound repair: A human fetal skin model. Development, 1992; 114: 253-259

[29] Ihara S., Motobayashi Y., Nagao E., Kistler A.: Ontogenetic transition of wound healing pattern in rat skin occurring at the fetal stage. Development, 1990; 110: 671-680

[30] Lo D.D., Zimmermann A.S., Nauta A., Longaker M.T., Lorenz H.P.: Scarless fetal skin wound healing update. Birth Defects Res. C. Embryo Today, 2012; 96: 237-247

[31] Chen W., Fu X., Ge S., Sun T., Zhou G., Jiang D., Sheng Z.: Ontogeny of expression of transforming growth factor- $\beta$ and its receptors and their possible relationship with scarless healing in human fetal skin. Wound Repair Regen., 2005; 13: 68-75

[32] Kishi K., Okabe K., Shimizu R., Kubota Y.: Fetal skin possesses the ability to regenerate completely: Complete regeneration of skin. Keio J. Med., 2012; 61: 101-108

[33] Gawronska-Kozak B.: Regeneration in the ears of immunodeficient mice: Identification and lineage analysis of mesenchymal stem cells. Tissue Eng., 2004; 10: 1251-1265

[34] Gawronska-Kozak B.: Scarless skin wound healing in FOXN1 deficient (nude) mice is associated with distinctive matrix metalloproteinase expression. Matrix Biol., 2011; 30: 290-300

[35] Gawronska-Kozak B., Bogacki M., Rim J.S., Monroe W.T., Manuel J.A.: Scarless skin repair in immunodeficient mice. Wound Repair. Regen., 2006; 14: 265-276

[36] Brant J.O., Yoon J.H., Polvadore T., Barbazuk W.B., Maden M.: Cellular events during scar-free skin regeneration in the spiny mouse, Acomys. Wound Repair Regen., 2016; 24:. 75-88

[37] Seifert A.W., Kiama S.G., Seifert M.G., Goheen J.R., Palmer T.M., Maden M.: Skin shedding and tissue regeneration in African spiny mice (Acomys). Nature, 2012; 489: 561-565

[38] Boehm T., Swann J.B.: Thymus involution and regeneration: Two sides of the same coin? Nat. Rev. Immunol. 2013; 13: 831-838

[39] Schlake T.: The nude gene and the skin. Exp Dermatol, 2001; 10: 293-304

[40] Mecklenburg L., Tychsen B., Paus R.: Learning from nudity: Lessons from the nude phenotype. Exp. Dermatol., 2005; 14: 797-810

[41] Flanagan S.P.: 'Nude', a new hairless gene with pleiotropic effects in the mouse. Genet. Res., 1966; 8: 295-309

[42] Gawronska B., Leuschner C., Enright F.M., Hansel W.: Effects of a lytic peptide conjugated to $\beta$ HCG on ovarian cancer: Studies in vitro and in vivo. Gynecol. Oncol., 2002; 85: 45-52

[43] Kopcewicz M.M., Kur-Piotrowska A., Bukowska J., Gimble J.M., Gawronska-Kozak B.: Foxn1 and Mmp-9 expression in intact skin and during excisional wound repair in young, adult, and old C57BI/6 mice. Wound Repair Regen., 2017; 25: 248-259

[44] Bukowska J., Kopcewicz M., Walendzik K., Gawronska-Kozak B.: Foxn1 in skin development, homeostasis and wound healing. Int. J. Mol. Sci., 2018; 19: 1956

[45] Lee D., Prowse D.M., Brissette J.L.: Association between mouse nude gene expression and the initiation of epithelial terminal differentiation. Dev. Biol., 1999; 208: 362-374
[46] Baxter R.M., Brissette J.L.: Role of the nude gene in epithelial terminal differentiation. J. Invest. Dermatol., 2002; 118: 303-309

[47] Brissette J.L., Li J., Kamimura J., Lee D., Dotto G.P.: The product of the mouse nude locus, Whn, regulates the balance between epithelial cell growth and differentiation. Genes Dev., 1996; 10: 2212-2221

[48] Prowse D.M., Lee D., Weiner L., Jiang N., Magro C.M., Baden H.P., Brissette J.L.: Ectopic expression of the nude gene induces hyperproliferation and defects in differentiation: Implications for the self-renewal of cutaneous epithelia. Dev. Biol., 1999; 212: 54-67

[49] Li J., Baxter R.M., Weiner L., Goetinck P.F., Calautti E., Brissette J.L.: Foxn1 promotes keratinocyte differentiation by regulating the activity of protein kinase C. Differentiation, 2007; 75: 694-701

[50] Calautti E., Li J., Saoncella S., Brissette J.L., Goetinck P.F.: Phosphoinositide 3-kinase signaling to Akt promotes keratinocyte differentiation versus death. J. Biol. Chem., 2005; 280: 32856-32865

[51] Janes S.M., Ofstad T.A., Campbell D.H., Eddaoudi A., Warnes G., Davies D.,Watt F.M.: PI3-kinase-dependent activation of apoptotic machinery occurs on commitment of epidermal keratinocytes to terminal differentiation. Cell Res., 2009; 19: 328-339

[52] Janes S.M., Ofstad T.A., Campbell D.H., Watt F.M., Prowse D.M.: Transient activation of FOXN1 in keratinocytes induces a transcriptional programme that promotes terminal differentiation: Contrasting roles of FOXN1 and Akt. J. Cell. Sci., 2004; 117: 4157-4168

[53] Kur-Piotrowska A., Bukowska J., Kopcewicz M.M., Dietrich M., Nynca J., Slowinska M., Gawronska-Kozak B.: Foxn1 expression in keratinocytes is stimulated by hypoxia: Further evidence of its role in skin wound healing. Sci. Rep., 2018; 8: 5425

[54] Weiner L., Han R., Scicchitano B.M., Li J., Hasegawa K., Grossi M., Lee D., Brissette J.L.: Dedicated epithelial recipient cells determine pigmentation patterns. Cell, 2007; 130: 932-942

[55] Meier N., Dear T.N., Boehm T.: Whn and $m \mathrm{Ha} 3$ are components of the genetic hierarchy controlling hair follicle differentiation. Mech. Dev., 1999; 89: 215-221

[56] Schlake T., Schorpp M., Maul-Pavicic A., Malashenko A.M., Boehm T.: Forkhead/winged-helix transcription factor Whn regulates hair keratin gene expression: Molecular analysis of the nude skin phenotype. Dev. Dyn., 2000; 217: 368-376

[57] Schlake T., Schorpp M., Nehls M., Boehm T.: The nude gene encodes a sequence-specific DNA binding protein with homologs in organisms that lack an anticipatory immune system. Proc. Natl. Acad. Sci. USA, 1997; 94: 3842-3847

[58] Pignata C., Fiore M., Guzzetta V., Castaldo A., Sebastio G., Porta F., Guarino A.: Congenital alopecia and nail dystrophy associated with severe functional T-cell immunodeficiency in two sibs. Am. J. Med. Genet., 1996; 65: 167-170

[59] Mecklenburg L., Nakamura M., Sundberg J.P., Paus R.: The nude mouse skin phenotype: The role of Foxn1 in hair follicle development and cycling. Exp. Mol. Pathol., 2001; 71: 171-178

[60] Kur-Piotrowska A., Kopcewicz M., Kozak L.P., Sachadyn P., Grabowska A., Gawronska-Kozak B.: Neotenic phenomenon in gene expression in the skin of Foxn1- deficient (nude) mice - 
a projection for regenerative skin wound healing. BMC Genomics, 2017; 18: 56

[61] Sousounis K., Michel C.S., Bruckskotten M., Maki N., Borchardt T., Braun T., Looso M., Tsonis P.A.: A microarray analysis of gene expression patterns during early phases of newt lens regeneration. Mol. Vis., 2013; 19: 135-145

[62] Heydemann A.: The super super-healing MRL mouse strain. Front. Biol., 2012; 7: 522-538

[63] Bukowska J., Walendzik K., Kopcewicz M., Cierniak P., Gawronska-Kozak B.: Wnt signaling and the transcription factor Foxn1 contribute to cutaneous wound repair in mice. Connect. Tissue Res., 2021; 62: 238-248

[64] Bukowska J., Kopcewicz M., Kur-Piotrowska A., SzostekMioduchowska A.Z., Walendzik K., Gawronska-Kozak B.: Effect of TGF $\beta 1$, TGF $\beta 3$ and keratinocyte conditioned media on functional characteristics of dermal fibroblasts derived from reparative (Balb/c) and regenerative (Foxn1 deficient; nude) mouse models.
Cell Tissue Res., 2018; 374: 149-163

[65] Gawronska-Kozak B., Kirk-Ballard H.: Cyclosporin A reduces matrix metalloproteinases and collagen expression in dermal fibroblasts from regenerative FOXN1 deficient (nude) mice. Fibrog. Tissue Repair, 2013; 6: 7

[66] Stemmer K., Kotzbeck P., Zani F., Bauer M., Neff C., Müller T.D., Pfluger P.T., Seeley R.J., Divanovic S.: Thermoneutral housing is a critical factor for immune function and diet-induced obesity in C57BL/6 nude mice. Int. J. Obes., 2015; 39: 791-797

[67] Donati G., Proserpio V., Lichtenberger B.M., Natsuga K., Sinclair R., Fujiwara H.,Watt F.M.: Epidermal Wnt/ $\beta$-catenin signaling regulates adipocyte differentiation via secretion of adipogenic factors. Proc. Natl. Acad. Sci. USA, 2014; 111: E1501-E1509

[68] Lanzini J., Dargère D., Regazzetti A., Tebani A., Laprévote O., Auzeil N.: Changing in lipid profile induced by the mutation of Foxn1 gene: A lipidomic analysis of Nude mice skin. Biochimie, 2015; 118: 234-243 